\title{
THE ENERGY AGENCY AS A PART OF AGRICULTURAL POLICY -THE ACTIVITIES AND LEGISLATIVE ISSUES
}

\author{
Milan Rapajićc ${ }^{1}$ SvetoPurić2 ${ }^{2}$ Srđan Vladetic ${ }^{3}$
}

\begin{abstract}
Summary
The authors of this paper have touched on two very important issues in Serbia, regarding the status of public agencies and the use of energy from renewable sources. Both issues have two sides - legal and economic, which are intertwined in the article. Public agencies operate in highly specialized areas of social life and have a wide range of different activities. That is the case with the activities of The Energy Agency, which should be the main promoter of the use of energy from renewable sources. For now, this independent regulatory body does not have the leading role and the paper proposes the extension of its jurisdiction. Due to the fact that Serbia is predominantly agricultural country, it has a real potential for energy production from renewable sources. These potentials are not used enough and the experience of other, highly industrialized countries in this area can be instructive in reaching measures in the field of energy policy, especially if you take into account the context of European integration, which must not ignore the requirements of environmental protection, and in which the advantages of using energy from renewable sources is particularly reflected. This paper presents the application of descriptive, legal and comparative methods.
\end{abstract}

Keywords: Activities of the Energy Agency, renewable energy, biomass, bioethanol, Energy Law, Agricultural policy, legislative issues.

JEL: $Q 40, Q 42$.

\section{Introduction}

The hypothesis is based, inter alia, on the fact that for Serbia the long-term financial perspective lies in profitable investments in renewable energy rather than in imported energy, such as oil and gas. The sub-hypotheses is that the process of Serbia's integration

1 Milan Rapaijć, M.A., Assistant, University of Kragujevac, Faculty of Law, Jovana Cvijića Street no. 1, 34000 Kragujevac, Serbia, Phone: +381 34306 523, E-mail: mrapajic@jura.kg.ac.rs

2 Sveto Purić, Ph.D., Full professor, University of Kragujevac, Faculty of Law, Jovana Cvijića Street no. 1, 34000 Kragujevac , Phone: +381 611932 146, E-mail: svetopuric@yahoo.com

3 Srđan Vladetić, Ph.D., Associate professor, University of Kragujevac, Faculty of Law, Jovana Cvijića Street no. 1, 34000 Kragujevac , Phone: +381 34306 567, E-mail: svladetic@jura.kg.ac.rs 
into EU leads to harmonization with the EU policies in the field of energy and energy efficiency, and the application of such policies brings about a significant improvement of energy efficiency in Serbia. That is why the decision of the Energy Law of the Republic of Serbia from 2014 and an explanation of the Bill given by the Government of Serbia which defines strategy as a document establishing the energy policy have been reviewed. Serbia does not have its own energy in an amount that would meet its needs (due to the lack of energy- much of it must be imported), but it is estimated that it has a large energy potential of renewable energy sources. Considering that, the paper presents the data dealing with how much of biomass as a basis for renewable energy is used in Serbia now and how it should be used in the future in terms of improvement. Agriculture is a big consumer, but it could also become a producer of energy. Bearing in mind the amount of biomass produced and the possibilities for its utilization, biomass is not sufficiently exploited.

The following sub-hypotheses is that the existence of a specific regulatory body, such as the Agency for Energy (there are such solutions in many other countries, such as Germany or even in our neighborhood, in Serbian Republic - Energy Regulatory Commission) represents a more flexible and efficient administrative and organizational model of promoting the use of energy from renewable sources than in the case of the existence of administrative units within the ministry. The reason is that the agency model of public administration is characterized by a greater degree of specialization, expertise, a greater degree of independence of the changing political constellations, neutrality and networking at EU level. The agency model of public administration aims to break big ministry and government organizations in order to create smaller units that are easier to manage, which are more flexible, with clearly defined rules and tasks, accountable, open and subject to review and which correspond to the idea of the governance oriented to the user (Musa,2012).

\section{The activities of the Energy Agency of the Republic of Serbia}

The Energy Agency, established by the Energy Law (Official Gazette N ${ }^{\circ}$ 57/2011, $80 / 2011,93 / 2012,124 / 2012$ ), is the regulatory body established in order to promote and direct the development of the electricity and natural gas, in accordance with the principles of non-discrimination and effective competition, through the creation of a stable regulatory framework, as well as to perform other tasks stipulated by the Energy Law (Article 36, Paragraph 1 of the Law on Energy, hereinafter referred to as the Law). The Energy Agency is responsible for issuing and revoking the license for performing the activities of electricity production and combined production of electricity and heat from renewable energy sources. The license is required if the total approved connection power of the plant is over $1 \mathrm{MW}$ - for the production of electricity; over $1 \mathrm{MW}$ of the total power and over $1 \mathrm{MW}$ of total heat power - for the combined production of electricity and heat in CHP plants and when it comes to biofuels - 1000t (or more) a year. We propose an extension function of The Energy Agency in the participation of creating a National Action Plan, which sets targets for renewable energy (and which are now set by The Ministry Of Energy) because the agency's management model 
has shown greater efficiency in this domain and it employs high level experts in this field (Mihajlović, 2014). Also, from the time when the Agency was formed in 2004, it has remained, by the name and form, of the same status, while every new government formed after the elections changed the ministries that were responsible for energy. It certainly does not benefit the continuous energy policy. The ministry responsible for energy would be the first instance body to which the National Action Plan, which sets targets for renewable energy, would be submitted. After any possible objections to the plan, it would be finished and then verified by the Government of the Republic of Serbia.

Agency in all fields of activities, should be focused on problems about using and promotion renewable resources energy. This is new field of administrative regulation by agency model in Serbia. ${ }^{4}$

This agency is a separate legal entity and is functionally independent from any of the state bodies, as well as all the organizations and individuals involved in the energy industry. The agency is a legal entity with rights, obligations and responsibilities established by law. As the agency has a wide field of activities, its operations, as well as regulating the rights and obligations of energy companies, which are under its jurisdiction, are regulated by the law governing the operations of companies, as well as other legislation, including the statute of the agency as a kind of "little constitution" for the internal organization and operations of the agency.

In order to perform duties in accordance with the principle of efficiency, regulating the rights and obligations as quickly and effectively as possible, the agency may, by the decision of the Council, organize performing outside its headquarters in the manner and under the conditions set forth in the statute of the agency. Considering the importance of the agency as an independent regulatory body of the legal system of Serbia, and in order that it would still be under some kind of non-permanent, but current control, the approval of the Statute of the Agency, passed by the Council as its highest body, is finally given by the National Assembly.

\section{The use of energy from renewable sources}

The use of energy from renewable sources is very important for Republic of Serbia 5 . The Energy Agency is one of the participants in the realization of these needs of Serbia. At the request of the Ministry of Energy, The Government of the Republic of Serbia

4 There is special Agency for Renewable Resources in Germany. This agency is a part of Federal Ministry of Food, Agriculture and Consumer Protection. See more about activities of this Agency on: Bioenergy in Germany: Facts and Figures, 2014, available on: international.fnr.de/service/ publications/ In Serbian Republic in 2002 The Energy Regulatory Commission of Serbian Republic was established. It is based on the Law on Electricity, it's a specialized, autonomous and independent, non-profit organization. The task of this public law body is to regulate the monopoly position and ensure the transparent and non-discriminatory position of all participants in the electricity market in Serbian Republic in accordance with the Law on Electricity.

5 In Article 65 of the new Law on Energy in 2014, explicitly states that the use of energy from renewable sources, in the interest of the Republic of Serbia.

EP 2016 (63) 1 (279-294) 
adopts the National Action Plan, by which targets for the use of renewable energy sources are established for a period of at least ten years.

The goals are established based on energy needs, economic opportunities, and obligations assumed by the Republic of Serbia through the ratified international agreements. The National Action Plan contains the information on energy share from renewable sources in gross final consumption of energy, the share of renewable energy in total energy consumption, the share of energy from renewable sources in the total energy consumption for heating and cooling, as well as the share of renewable energy in the total energy consumed in all forms of transport. The National Action Plan for renewable energy sources states that: "Renewable energy sources, with an estimated technically exploitable potential of about 5.6 Mtoe per year can significantly contribute to the lower use of fossil fuels and the attainment of set targets on the share of renewable sources in gross final consumption of energy, as well as the improvement of the environment. The biomass potential is about 3.4 Mtoe per year (2.3 Mtoe is unused, and 1.1 Mtoe is already in use), 1.7 Mtoe in hydropower ( 0.8 Mtoe per year is unused, and 09 Mtoe per year is exploited hydropower potential), 0.2 Mtoe per year in geothermal energy, 0.1 Mtoe per year in wind energy, 0.2 Mtoe per year in solar energy and 0.04 Mtoe per year in the biodegradable part of waste. The Republic of Serbia is already using $35 \%$ of the available technical potential of renewable energy ( 0.9 Mtoe of used hydro potential and 1.06 Mtoe of the biomass potential and geothermal energy). "

The National plan for the use of renewable energy includes measures and the estimated financial resources for the realization of the planned share of energy from renewable sources, as well as the implementers and deadlines for the achievement of the planned activities. The National Action plan must comply with the regulations governing energy efficiency and reduce emissions that cause the greenhouse effect. The Ministry of Energy monitors the implementation of the National Action Plan and submits an annual report to the government.

The activity of the Energy Agency, the Ministry of Energy and the Government of the Republic of Serbia, should encourage the production of renewable energy sources. Renewable energy is sometimes also described as permanent energy source and an energy resource, which is used to produce electricity or heat, or in any work, the reserves of which are constantly or cyclically renewed. The very term "renewable" (Šljivac, Simic, 2009), as well as "permanent" indicates the fact that the energy is consumed in an amount which does not exceed the rate at which it is produced in nature. Sometimes the term "renewable energy sources" refers to those which are said to have so many reserves that can be exploited for millions of years. We can find attitude in theory that the primary supply sector includes fossil fuels (coal, oil, natural gas, etc.), industrial by-products (blast furnace gas and cookery gas) and local renewables (biomass, solid waste and natural resources). All the primary energy flows

6 The National Action Plan for the use of renewable energy sources of the Republic of Serbia, the Ministry of Energy, Development and Environmental Protection, Belgrade, 2013, 7 
are evaluated in tons of oil equivalent (toe) units. This sector provides for electricity and heat production deriving from large-scale as well as small-scale technologies and for other needs directly in the end-use sector (Cormio, et. al., 2003). This is in contrast to non-renewable resources, where reserves are estimated at tens or hundreds of years, whereas their creation took tens of millions of years. Energy Law, Article 2, Section 47 refers to the energy from renewable sources. According to the law, it is the energy generated from neo fossil renewable sources, such as waterways, biomass, wind, solar, biogas, landfill gas, gas from the plant for sewage treatment and geothermal energy. About significance of energy of wind, Soteris A. Kalogirou writes that therefore, it can be concluded that, purely on a theoretical basis, and disregarding the mismatch between supply and demand, the wind could supply an amount of electrical energy equal to the present world electricity demand (Kalogirou, 2005). Also about renewable sources it is said that, the rapid evolution of renewable energy sources (RESs) during the last two decades resulted in the installation of many RES power systems all over the world. A disadvantage of RES systems is that the installation cost is still high, so their design optimization is desirable (Koutroulis, Kalaitzakis, 2003).

In theory, for example, one of the renewable sources of energy, such as biomass, is defined as fuel derived from plants or parts of plants, such as wood, straw, stalks of grain, shells, etc. Biomass as a renewable energy can be generally divided into wood, non-wood and animal waste. The term "wood" refers to residues from forestry and waste wood, then wood grown biomass, for example, the fast-growing trees. The nonwood biomass refers to fast-growing algae and grass. Also, biomass includes waste and waste from agriculture, animal waste and other residues. Wood is most commonly used, which is formed as a by-product or waste and residues that can no longer be utilized. Such biomass is used as fuel in power plants to produce electricity and heat, or it is processed into gaseous or liquid fuels for use in vehicles or homes. The Energy Development Strategy of the Republic of Serbia states that: "Biomass is an important energy potential of the Republic of Serbia. The potential of biomass is estimated at 3.448 million tons and in the total potential of renewable energy it accounts for $61 \%$. The majority of this potential lies in woody biomass - 1.53 million tons and then the agricultural biomass - 1.67 million tons (remains in crop production, animal husbandry, fruit growing, vine growing and primary processing of fruits), while the potential of biodegradable municipal waste is estimated at 205 thousand tons. Biodegradable waste (other than municipal) includes waste edible oils and animal waste (rendering slaughter waste) in a total amount of 0.043 million tons / year." The potential of renewable energy sources is enormous as they can in principle meet many times the world's energy demand. Renewable energy sources such as biomass, wind, solar, hydropower, and geothermal can provide sustainable energy services, based on the use of routinely available, indigenous resources. A transition to renewables-based energy systems is looking increasingly likely as their costs decline while the price of oil and gas continue

7 The Energy Development Strategy of the Republic of Serbia until 2025 with projections to 2030, the National Assembly of the Republic of Serbia, 2015, 8

EP 2016 (63) 1 (279-294) 
to fluctuate. In the past 30 years solar and wind power systems have experienced rapid sales growth, declining capital costs and costs of electricity generated, and have continued to improve their performance characteristics (Herzog, et. al., 2013).

In the most important agricultural region of Serbia, in the autonomous province of Vojvodina there is the greatest potential of agricultural residues (straw, soybeans, wheat, barley and corn remains), and other plant residues and waste from livestock production that can be converted into biogas. Moreover, as a major producer of cereals and industrial crops (soybean, sunflower, canola, etc.), Vojvodina has great potential for the production of biofuels (biodiesel and ethanol). The suitability of renewable energy sources is reflected in the fact that they are inexhaustible natural form of energy that is all around us.

In Serbia, the distribution of resources of renewable energy ranges as follows: in the first place there are bio-renewable energy sources, for example, biomass, solar energy, small rivers, wind energy and geothermal energy. Energy Law also defines some of these renewable energy sources. Thus, in Article 2 (paragraphs 3.4 and 5), definitions of some forms of renewable energy are given. According to the legal definition, biomass means the biodegradable fraction of products, waste and residues of biological origin from agriculture (including vegetal and animal materials), forestry and related industries, as well as the biodegradable fraction of industrial and municipal waste.

Biofuels are also, as already mentioned, renewable energy, their legal definition being - the liquid or gaseous fuel for transport, produced from biomass. Bio-liquid is the fuel used to produce electricity and thermal energy for heating and cooling, also produced from biomass, except for the traffic. Article 2 of the Energy Law also defines what the warranty of the origin of the product means. In terms of the law, it is a document that has the sole function to prove the final customer that a given share or quantity of energy is produced from renewable energy sources, as well as the combined production of electricity and heat with high efficiency of primary energy. The warranty of origin for the amount of energy produced in a given period will be issued only once and is a document in electronic form, valid for one year from the date of issue and it is portable.

The paper has pointed out that the use of electricity from renewable energy sources is the important for the Serbian economy, and considering the fact that Serbia is a country rich in agricultural regions, the use of renewable energy in agriculture is also an important national-economic interests of Serbia. The Energy Law relatively extensively prescribed what the incentives to use renewable sources for electricity production are. In terms of legal norms, incentives for renewable electricity production include the obligation to purchase electricity from a privileged producer, the price at which this energy is purchased and the period of validity of the obligation to purchase the electricity, as well as taking over the balance sheet liability.

The public supplier is obligated to purchase electricity from the privileged producer, under a contract for the purchase of electricity, in accordance with the Energy Law and secondary legislation passed by the Ministry of Energy and the Energy 
Agency in accordance with the law. At the request of the energy subject that has gained temporary status of a privileged producer, the public supplier shall, within thirty days from the date of the application, conclude a preliminary contract for the purchase of electricity. The public supplier on the other hand is not obliged to enter into a contract to purchase electricity from a privileged producer, if the energy entity does not acquire the final status of privileged producer, but remains in a temporary status. Means to incentivize the use of renewable energy are provided by the final customers, who pay for a separate fee for the incentive, in addition to the access to the transmission or distribution system bill and these two are reported separately. Government, as the central organ of executive power, at the request of the competent ministry (and in this case it is the Ministry of Energy and Mines), provides for incentives for the production of electricity using renewable energy sources and for the purchase and consumption depending on the type and strength of a plant. Government prescribes the prices at which electricity is purchased from the privileged producers, the period of validity of the price and the obligation to purchase the electricity. Also, government provides for obligations on balance responsibility, content and duration of the pre-contract and contract to purchase electricity from the privileged producers as well as the method of calculation of incentive compensation and allocation of funds on that basis. At the request of the Ministry, Government determines the amount of compensation to be paid for incentives for renewable energy not later than the end of December of the current year for the following year. Because of its importance, this fee must be published in the Official Gazette of the Republic of Serbia.

A privileged producer has the right to use the incentives, then they have a priority in taking over the total electricity into the transmission or distribution system, except in cases of threatened safety of operation of these systems. A privileged producer has the right to use tax incentives, exemptions in customs clearance, or the right to subsidies and other incentives. Since this is a sensitive area (because of the high profitability of the very economic activity in the energy sector different misuses are possible), the cases in which the energy operator loses the status of a privileged producer are defined by the law. The energy operator will lose the status if the decision on acquiring the status is based on false data.

Since the oil reserves in the world are exhaustible, biofuels will be used more and more, not only in the transport sector, but also in different types of production. The authority having jurisdiction over prescribing the mandatory share of biofuels in the transport sector and measures for its purchase is the Government of the Republic of Serbia. The government also provides incentives for biofuel production. So the government, at the request of two ministries: the Ministry of Energy and the Ministry responsible for the environment, determines the criteria for the sustainable production of biofuels. There are two kinds of biofuels- bioethanol and biodiesel. Bioethanol is a type of ethanol produced from biomass or biodegradable parts of waste to be used as biofuel. In theory, bioethanol is defined as "one of the most important alternative renewable sources of energy that belongs to biofuels (in addition to biodiesel, bio-methanol etc.). It is 
obtained by fermentation of renewable raw materials, i.e. the fermentation of sugars present in biomass or sugar obtained by previous enzymatic conversion of biomass components. It is a significant substitute for fossil fuels and in many countries it is already being used as an additive to petrol, so it is classified as a strategic raw material. "(Nikolic, 2009)

So the specificity of bioethanol is that it can be used in internal combustion engines in addition to petrol, or as its substitute. For example, adding no more than $20 \%$ of ethanol into petrol does not require any modifications to the car engine that uses the specified percentage of petrol mixed with bioethanol. Greater percentages of bioethanol require modifications of the engine. Vehicles using bioethanol as fuel are more expensive than vehicles using petrol (5-10\%).

However, the countries qualified by the economic policy as agricultural, which Serbia certainly is, can see the opportunity for their future exports in this. The highly industrialized countries, the so-called big car producers, are looking for those markets which have significant resources of ingredients that produce bioethanol. The fertile fields of Vojvodina may be more used as the base for the production of bioethanol in the future.

Today, the situation in Serbia when it comes to the production of bio-ethanol as a fuel is far from ideal. The production and consumption of bio-ethanol as a motor fuel is not sufficiently developed and organized in Serbia, so that our country imports a significant portion of motor fuels. Examples from other countries show that the introduction of incentive programs in the Energy Policy depends on the government and its assistance. Serbia should adopt appropriate programs that would include the production of bioethanol for fuel and the substitution of motor fuel with bioethanol. Since we are a European country determined to join the EU, the measures in this field should probably be similar to those of the European Union.

The legislation of the European Union functions with directives and recommendations, thus creating a unified legal framework in all areas of social life of member countries. The detailed provisions of the directives are left to the member countries. For example, in order to promote biofuels and other alternative forms of fuel, though mainly for road transport, two directives were adopted in 2003: Directive 2003/30/EC, which requires from member countries to produce or provide the market with a minimum amount of biofuels, which would meet the goal to substitute $2 \%$ of fossil fuels by the end of 2005 and $5.75 \%$ by the end of 2010 , compared to the energy content. The EU member countries obliged in 2004 to submit annual reports on the actions in this plan to the competent bodies of the EU. Directive 2003/96/EC provides an opportunity for Member Countries to apply different taxes on these fuels in order to encourage the development of this type of fuel. In 2002 already, nine EU countries (Germany, France, the UK, Italy, Spain, Poland, Sweden, Austria and the Czech Republic) fully or partially were freed from taxes for biofuels. The main objectives of the European Directives (which in future will increasingly regard Serbia as its entry into the European Union is expected) can be summed up in a few aspects. The first aspect is reflected in 
the fact that the European Union depends on external sources of fuel. The European Union currently imports about 50\% of energy, which may have reached $70 \%$ by 2030 . As for oil, the situation with numbers is even worse. It is discouraging that the EU dependence on oil export will increase to $90 \%$ in 2020 . The next aspect is to achieve the goals of the Kyoto agreement, which was signed in 1997, and to reduce the gas emission that contributes to greenhouse effect. Of six chemical compounds and gases that influence the greenhouse effect most attention is paid to carbon dioxide - CO2. According to the above Kyoto agreement, it is necessary to reduce the emission of carbon dioxide in the period from 2008 to 2012 for about 5\% in comparison to 1990 , which has been done to a great extent. One of the aspects of the above directives and their integral objectives is to reach the figure of $20 \%$ of substitute of traditional fuels in road transport by 2020. Directive 2003/30/EC mostly relates to fuels used in road transport, since they are considered to participate with more than $85 \%$ of the total fuel of the EU transport. Regarding the existing capacity, the directives adopted and the accompanying regulations, it is obviously necessary for the EU to take energetic steps to increase the capacity of ethanol production. This statement also applies for Serbia. The goal of the EU was to substitute $2 \%$ of fossil fuel by the end of 2005 , according to Directive 2003/30/EC, which was not done. We must stress that, in the period from 2003 to 2005, ten of the EU member countries did not use either biodiesel or bioethanol as fuel. Almost ten years ago, in 2005, two EU countries with the highest share of bioethanol as biofuel used were Germany and Sweden. Considering these data, it can be concluded that the estimates that biofuels will substitute $20 \%$ of traditional fuels by 2020 are not realistic. It is realistic, considering the present state, that this percentage will reach about $10 \%$. This assessment was carried out in the energy policy of the EU (Energy Policy Document), adopted in 2007.

\section{The situation in Serbia and a brief review of its agriculture in the area of production of certain renewable energy}

On the territory of the northern Serbian province of Vojvodina (once part of the AustroHungarian Empire) the first plant for the production of ethanol was built. This fact shows that Vojvodina, as the largest agricultural region in Serbia, is potentially the most fertile ground for the development of renewable energy, which has been proved in the past and the Government of the Republic of Serbia is still expected to improve it, through its economic policies, the incentives to manufacturers and potential manufacturers and thus give them economic stimulus. During the sixties of the twentieth century a serious development of ethanol production in Serbia began, along with the formation of large industrial capacity with modern equipment and technology.

In Serbia in 1996, there were a dozen of producers whose daily collective capacity stood at just over $150,000 \mathrm{hl}$, corresponding to the annual capacity of approximately 48 million hl if the calculation takes 320 working days ${ }^{8}$.' In Serbia, there are opportunities for the production of bioethanol and biodiesel. The raw materials used for the

$8 \quad 1$ hl equals 11 of absolute alcohol

EP 2016 (63) 1 (279-294) 
production of bioethanol are grain, sorghum, Jerusalem artichoke and potatoes. For the production of biodiesel oilseeds can be used - sunflower, soybean and canola, as well as waste edible oils. All the above raw materials can be considered a potential for the production of biofuels only after satisfying all other requirements. It is estimated that the market surplus of grain is more than one million tons, but its use for the production of bioethanol is economically justified only in cases where it cannot be exported and in cases where it is not possible to ensure the production of bioethanol from lingo cellulosic biomass (Vukoje, 2013). Also, according to estimates, there are about 100,000 hectares of marginal land in Serbia, that can be used for the cultivation of sorghum and Jerusalem artichoke, which could produce about 200 thousand tons of ethanol per year. The cultivation of oilseeds for biodiesel production could be carried out on 350,000 hectares, which would allow the production of about 220,000 tons of biodiesel. It is estimated that about 10,000 tons of waste edible oil suitable for biodiesel production can be collected annually" (The Energy Development Strategy, 2015). Today in our country the production of ethanol based on cereals is at a rate of about $50 \%$, whereas the rest of it is based on molasses. Although during the nineties Serbia was under the heavy burden of economic sanctions, the ethanol production was at a higher level than it is today. The largest of three plants for the production of ethanol are in the political and economic center of Serbia - Belgrade and at two locations in Vojvodina - Crvenka and Kovin. Over $80 \%$ of the production of this substance in Serbia is carried out in these three plants.

The theory states that none of these systems has the equipment for dehydration of ethanol. In this sense, we should expect the proposals of professional associations in central and regional chambers of commerce, but above all of the government ministries and the Energy Agency. We must emphasize that the Energy Agency of the Republic of Serbia, as an independent regulatory body, has a broader mission in the economic and legal system of Serbia, which is to, at the normative level, create a legal framework to facilitate the production and use of renewable energy.

If we look more broadly at the social role of the Agency, its leading management has an obligation to respect the public interest and by promoting it, informs the executive government of the necessity of modernizing and improving the production process of renewable energy sources in accordance with the requirements of the modern global market. Our claim is supported by the fact that the production of ethanol, for example, in 2005 was nearly at the level of production achieved in 1985, but was significantly lower than the amount of ethanol produced in 1991. During the same period, the production of ethanol in the world doubled. The trend of growth in Serbia was similar, until 1991 when production began to decline. Even the production growth that was achieved from 1999 to 2005 is not the true, realistic, picture, due to the mentioned economic blockade of Serbia - the sanctions of the United Nations. Most of the existing facilities do not work effectively for different reasons.

Among the reasons of why it is not effective, we can mention: the total state of the economy, the negative tendencies in terms of total production, the inadequate 
legislation, the classification of ethanol under legislation standardized for wine and spirits. This practically narrows the possibility of using ethanol for other purposes for which it is used in the world, for example in the chemical industry and fuel industry. Along with the stagnant production in the field of renewable energy, several factors coincide: bad government policy regarding the development strategy of the industry in general, the inability of consolidation after a period of crisis and stagnation and in some cases outdated equipment. If we look at the production in our country through the prism of the adopted EU directives (2003/96/EC and 2003/30EC), the targets set for 2020 are actually unfulfillable. It is important to mention that in Serbia today there is no organized consumption and production of bio-ethanol as a motor fuel. The Republic of Serbia is the importer of a significant part of their consumption of motor fuels.

We will further focus on the use of biomass from agricultural waste as a renewable energy source. It has already been noted in this paper that biomass is renewable, biodegradable organic matter of vegetable or animal origin, as well as biodegradable fraction of industrial and municipal waste that transforms into multiple forms of energy through different processes. The resulting energy is primarily used for the production of electricity and heat. The fact that the energy in biomass is of chemical nature, makes this energy constant.We used data from Renewable Energy Data Book, 2012, U.S. Department of Energy, which evidence about significance of biomass and other renewable sources in the first economy in the world : In 2012 in the United States, biomass produced about $11 \%$ of total renewable electricity generation, wind produced $28 \%$, solar (photovoltaics and concentrating solar power) produced $3 \%$, hydropower produced $55 \%$, and geothermal produced $3 \%$. In contrast to the solar energy, the energy of the biomass is no downtime. Another difficulty in agricultural production in Serbia is reflected in the fact that it is difficult to estimate the current amount of waste. Most of the waste is treated or disposed of in the area in which it is created. It is often destroyed in the same place, although it could be used for other, more useful purposes.

Waste can generally be divided into controlled and uncontrolled waste, but both groups actually represent biomass such as wood waste (unused and waste wood, remains of tree stumps and $\operatorname{logs}$, semi-wild trees and the like), breeding fast-growing trees and fast-growing algae and grasses, residues and waste from agriculture (natural liquid manure, straw, leaves, husks, cobs of different crops (sugar beet, sugar cane, corn), energy crops (turnips and potatoes), industrial waste (from the industry that produces organic waste - the beverage industry and food industry) and finally municipal waste such as paper and plant remains should be mentioned.

Energy from biomass can be produced in several ways. The types of biomass energy include: 1. direct burning of wood, wood waste and crop residues for thermal energy production; 2. digestion, i.e., processing animal waste (manure) into biogas; 3 . processing biomass into alcohol (ethanol) or the production of vegetable oils. (Djordjevic, 2008). In Serbian agriculture there are large amounts of crop residue that can be partly used for energy purposes, so it is unacceptable to remove all plant debris from soil, in order not to deplete the soil and not to disrupt the natural cycle of circulation of matter in it. 
As a result of ignorance of what to do with plant residues, it is usually burned in the fields, which is very harmful.

Also, biomass from livestock production represents a significant energy source. The energy generated from liquid manure during exploitation does not emit harmful gases that are produced during combustion of conventional fossil fuels, thus contributing to greater environmental protection. For example, about 10-12 pounds of liquid manure with $4-10 \%$ of dry matter is needed to obtain one cubic meter of gas. (Furman, et. al., 2007). The domestic animals from which liquid manure can be used to produce biogas are dairy cows, cattle, fattening pigs and laying hens. This description, when it comes to energy from biomass, clearly leads to the conclusion that the Serbian agriculture has certainly great potential in this field.

Therefore, the question is where the problem lies. The problem is investing in systems for the production of biogas. Exploitation is a pure loss, if the energy spent on the extraction and processing of energy is higher than the energy gained from this resource. The goal is to create a system of self-supporting. If the economic policy of the Government of Serbia, established on April 27th 2014, moves in the direction of encouraging new forms of production within agriculture, it can be expected in the future that the investment in the plant to produce energy from biomass will enable progress in the development of not only agriculture, but also energy, environment protection and, generally, of every region which chooses to use them. This state is supported by a realistic reason, since Serbia's potentials in biomass are not small. With its area of 88 361 square kilometers, Serbia is a country rich in agricultural land. This is supported by the fact that there are about 45000 square kilometers of farmland in Serbia. Even 24 000 square kilometers in Serbia are covered by forest. As noted by Brkic and Furman, it is annually produced about 13 million tons of biomass in Serbia (Brkic, Furman, 2004), where the production of Vojvodina is $70 \%$, i.e. 9 million tons of biomass. The first constructions of the plants and facilities for the use of biomass for energy purposes began in Vojvodina. The Republic of Serbia is certainly aware of the importance of renewable energy and is one of the members of the international organization for renewable energy - the IRENA (International Renewable Energy Agency).

\section{Summarized concluding remarks}

Serbia is nowadays deeply involved in the process of European integration, becoming a candidate country for EU membership. This path requires the fulfillment of obligations relating to energy policy in the field of (agro) Economy and the mosaic of Serbian legal regulations, which should completely comply with a number of European directives in the field of energy, and the objectives of which have already been mentioned in this paper. Accepting the principles of European energy policy requires the fulfillment of obligations related to environment protection. The EU environmental law requires the Serbian reduction of carbon dioxide into the air. Using biomass instead of liquid fuel significantly reduces environmental pollution. The combustion of biomass does not increase the content of carbon - dioxide in the atmosphere and does not create a 
greenhouse effects, it does not even create hazardous ash.

It is necessary to improve the Energy law at the normative level and adapt EU legislation, since the EU has long tradition in the use of biomass for energy purposes. Although this law introduced subsidies to producers of renewable energy, it is necessary to encourage foreign direct investment in this area. By including the domestic economy in the development of technology, equipment production and the training of future producers of energy from renewable sources, the public awareness of the importance of this issue would be raised. The fact that renewable energy sources are in rural areas can provide greater employment of the people from rural areas, which would improve the economy in the country and raise the level of gross domestic product. Broader social and positive implications would lead to stopping negative migrations from villages to cities, in a word -to the revival Serbian villages.

However, in the past more and today a little less, there are obstacles to the development of renewable energy sector in Serbia. The responsibilities of the operator to give priority in connecting to the grid to the producers that use renewable energy sources and in dispatching renewable energy are still not clearly defined; there is a lack of a substantial number of equipment and processes standards for the exploitation of renewable energy sources; there is an insufficient number of regulations for the design, construction, inspection, assembly and installation of devices that use renewable sources of energy; there is an insufficient number of accredited laboratories certified for plants using renewable energy sources; there are non-economic price of electricity and the disparity in energy prices. In addition to these obstacles, we should mention the additional problems, such as costly bank loans for projects using renewable energy sources, complicated and lengthy procedures for issuing permits and approvals for construction projects facilities for renewable energy exploitation, the insufficiently supportive tax and subsidy system for renewable energy and the lack of public awareness about the importance of using renewable energy sources. When the renewable energy sector is still developing, the incentives are necessary, which should be in compliance with state policies. In order to overcome barriers and realize the aims, it is necessary, first of all, to establish an effective legislative framework for the sustainable use of renewable energy sources, then to remove the administrative obstacles mentioned above. It is also necessary to establish an effective institutional and organizational framework for the sustainable use of renewable energy sources which includes the strengthening of the administrative capacity for the sustainable use of renewable energy sources. In practice, it is necessary to introduce additional incentives for those who implement energy efficiency measures and for those who produce and use renewable energy sources. It is stated here because the Law on Energy from 2014 formed the legal basis in terms of improving procedures in the field of renewable energy and they include the following incentives for investors who plan to use this type of energy source: all producers that use renewable sources of energy can achieve a temporary status and thus increase the bankability of their projects; in addition to temporary status, the status of privileged producer of electricity is introduced as well as the status of producers of renewable energy, which creates a precondition that all producers who use renewable source manage to obtain the guarantee of origin; a new model contract for 
the purchase of electricity from the suspensive condition was introduced instead of three previous contracts. An investor who plans to use renewable energy sources for electricity production will have all the conditions and incentive measures in the trial period defined prior to the start of construction and after acquiring the status of a privileged producer. At the end we want to stress that "education, strong vision and commitment could be the basis for strengthening renewable energy sources in Serbia". If we recall the beginning of the last century, electricity was only one" innovation ", which only caused a lot of doubt and resistance with many people. Fortunately for the world, there were those who saw the future in it, there were financiers who could understand the value of the "innovation" and all its possibilities. If we only consider this period of global energy history, we will understand today's effort to turn to the new, cheaper and cleaner forms of energy. ${ }^{9}$

However, the legal form, which is the basis of this work, should not be forgotten. That means that we need to fuse many competencies related to renewable energy under the auspices of the Energy Agency, which are now split among the Government, relevant ministries (Ministry of Energy and Mines and the Ministry of Agriculture and Environment) and the Agency. To this end, we propose the establishment of the Special Council of the Energy Agency, which would be called the Council for energy efficiency and renewable energy. The Council would also be a special advisory body of the President of the Republic of Serbia. The council would include the representatives of the faculty departments and research institutes involved in the study of energy efficiency and energy production from renewable sources, special advisors of the relevant Ministers in the field of renewable energy, a member of the Chamber of Commerce of Serbia, as well as President of the Council of the Energy Agency and at least one staff officer of the Agency with narrow expertise on renewable energy. The special council for energy efficiency and renewable energy of the Energy Agency, which is also an advisory body of the President of the Government, would, among all, perform similar work to that performed by the abolished Energy Efficiency Agency. We believe that this would benefit to the realization of national interests, which is reflected in a variety of incentives built into renewable energy.

\section{Sources:}

1. Brkic, M., Furman, T. (2004). Obnovljivi izvori energije u poljoprivredi. Traktori i pogonske mašine, No. 9, Belgrade, pp. 12-18.

2. Bioenergy in Germany Facts and Figures (2014), available at: www. international.fnr.de/service

3. Cormio, C., Dicorato, M., Minoia A., Trovato M. (2003): A regional energy

9 A bankability project is the project that is sufficiently powerful, prestigious and stable to ensure profitability - the project that is sustainable. This project has provided cash flow, which means that the project is well conceived from legal, technical and economic aspects. It is also the project for which it is easy to provide investors (commercial banks) who are ready to finance because they recognize that the cash flows are stable and that their investment will be returned. In the end it is a project for which there is quality collateral, acceptable to the bank, i.e. reliable and thus quickly and easily enforceable. 
planning methodology including renewable energy sources and environmental constraints, Renewable and Sustainable Energy Reviews, No. 7, pp. 104-105.

4. Djordjevic, B. (2008): Objektivno vrednovanje obnovljivih energija. Vodoprivreda, No. 40, Belgrade pp. 19-38.

5. Eftichios, K., Kalaitzakis, K. (2003): Development of an integrated dataacquisition system for renewable energy sources systems monitoring, Renewable Energy, No. 28, pp. 139-140

6. Furman, T., Nikolic, R., Tomic, M., Savin, L., Simikic, M. (2007): Alternativniobnovljivi izvori energije u poljoprivredi. Traktori i pogonske mašine, No. 12, Novi Sad pp. 7-10.

7. Herzog, A.V., Lipman, E.T., Kammen D.M. (2013): Renewable Energy Sources, This report is to be published in the Encyclopedia of Life Support Systems (EOLSS) Forerunner Volume"Perspectives and Overview of Life Support Systems and Sustainable Development," Part 4C. Energy Resource Science and Technology Issues in Sustainable Development - Renewable Energy Sources, available at: http://www.eolss.com.

8. Kalogirou, A. S., (2005): Seawater desalination using renewable energy sources, Combustion Science 31.

9. Mahler, J. (1997): Influences of Organizational Culture on Learning in Public Agencies, Journal of Public Administration Research and Theory: J-PART, Vol. 7, No. 4, pp.519-520

10. Mihajlović, M. (2014): Menadžment znanja kao factor povećanja efikasnosti organizacije, Oditor, no. 9, pp. 33-38, CEFIS, Beograd, Srbija.

11. Musa, A. (2012): Agencifikacija kao nova i dodatna centralizacija - hoće li se Hrvatska ikada moći decentralizirati - Croatian and comparative public administration, No. 4, p. 1210

12. Nikolić, S. (2009): Proizvodnja bioetanola kao alternativnog goriva iz kukuruza pomoću slobodnog i imobilisanog kvasca, doktorska disertacija, Tehnološkometaluški fakultet Univerziteta u Beogradu.

13. Osborne, D. (1993): Reinventing Government, Public Productivity \& Management Review, Fiscal Pressures and Productive Solutions: Proceedings of the Fifth National Public Sector Productivity Conference, Vol. 16, No. 4, p. 356.

14. Vukoje, A. (2013): Faktori egzistencije kao uslov stvaranja tržišne pozicije preduzeća, Oditor, no. 5, pp. 27-37, CEFIS, Beograd, Srbija.

15. The Energy Development Strategy of the Republic of Serbia until 2025 with projections to 2030, The National Assembly of the Republic of Serbia, 2015, 8

16. The National Action Plan for the use of renewable energy sources of the Republic of Serbia, the Ministry of Energy Developement and Environmental Protection, 2013, Belgrade, p. 7 
17. Šljivac, D., Simic, Z. (2009): Obnovljivi izvori energije - vrste, potencijali, tehnologije. U publikaciji: Obnovljivi izvori energije u strukovnom obrazovanju, Zagreb.

18. Zakon o energetici, Službeni glasnik RS no. 57/ 2011, 80/ 2011, 93/2012, $124 / 2012$.

\title{
АГЕНЦИЈЕ ЗА ЕНЕРГЕТИКУ- КАО ДЕО ПОЉОПРИВРЕДНЕ ПОЛИТИКЕ - ДЕЛАТНОСТ И ЛЕГИСЛАТИВА
}

\author{
Milan Rapajic ${ }^{10}$, Sveto Puric ${ }^{11}$, Srđan Vladetic ${ }^{12}$
}

Rezime

У раду, аутори су се дотакли две веома значајне теме у Србији које се тичу положаја јавних агенција и коришћења енергије из обновљивих извора. Обе теме имају своје две стране- правну и економску, које се у чланку преплићу. Јавне агенције су значајни субјекти српске јавне управе, које делују у уско специјализованим областима друштвеног живота. Те области се крећу у широком дијапазону разноврсних делатности. Управо је такав случај са делатношћу Агенције за енергетику која треба да буде главни промотер коришћења енергије из обновљивих извора. С обзиром на чињеницу да је Србија претежно пољопривредна земља, она има реалне потенцијале за производњу енергије из обновљивих извора. Ти потенцијали нису довољно искоришћени, а искуства других високо индустријализованих земаља у овој сфери могу да буду поучна приликом доношења мера из сфере енергетске политике, посебно ако се узме у обзир контекст европских интеграција, који не сме да пренебрегне захтеве заштите животне средине, а у чему се посебно огледа позитивност коришћења енергије из обновљивих извора. У раду је извршена примена дескриптивног, правног и упоредног метода.

Кључне речи: Делатност Агенције за енергетику, обновљиви извори енергије, биомаса, биоетанол, Закон о енергетици, пољопривредна политика

10 Asistent, master Milan Rapajić, Univerzitet u Kragujevcu, Pravni fakultet, Ulica Jovana Cvijića br. 1, 34000 Kragujevac, Telefon: +381 34306 523, E-mail: mrapajic@jura.kg.ac.rs

11 Redovni profesor, dr Sveto Puric, Univerzitet u Kragujevcu, Pravni fakultet, Ulica Jovana Cvijića br. 1, 34000 Kragujevac, Telefon:+381 611932 146, E-mail: svetopuric@yahoo.com

12 Vanredni profesor, dr Srđan Vladetić, Univerzitet u Kragujevcu, Pravni fakultet, Ulica Jovana Cvijića br. 1, 34000 Kragujevac, Telefon: +381 34306 567, E-mail: svladetic@jura.kg.ac.rs 